Article

\title{
Calprotectin (S100A8/S100A9) and Myeloperoxidase: Co-Regulators of Formation of Reactive Oxygen Species
}

\author{
Arne Bøyum ${ }^{1,4, *}$, Knut Kristian Skrede ${ }^{1, \dagger}$, Oddvar Myhre ${ }^{1}$, Vivi-Ann Tennfjord ${ }^{1}$, Christine \\ Gran Neurauter $^{2}$, Helge Tolleshaug ${ }^{3}$, Eirunn Knudsen ${ }^{4}$, Per Kristian Opstad ${ }^{1}$, \\ Magnar Bjørås ${ }^{2}$ and Haakon B. Benestad ${ }^{4}$
}

1 Norwegian Defence Research Establishment, Division for Protection, P.O.B. 25, 2027 Kjeller, Norway; E-Mails: Oddvar.Myhre@ffi.no (O.M.); tenv@sb-hf.no (V.-N.T.);

Per-Kristian.Opstad@ffi.no (P.K.O.)

2 Institute of Medical Microbiology, National Hospital, 0027 Oslo, Norway; E-Mails: Christine.Gran@rr-research.no (C.G.N.); Magnar.bjoras@rr-research.no (M.B.)

3 Department of Molecular Biosciences, University of Oslo, P.O. Box 1041 Blindern, NO-0316 Oslo, Norway; E-Mail: Helge.Tolleshaug@online.no (H.T.)

4 Department of Physiology, Institute of Basic Medical Sciences, University of Oslo, P.O.B. 1103 Blindern, N-0317, Oslo University of Oslo, Norway; E-Mails: eirunn.knudsen@medisin.uio.no (E.K.); h.b.benestad@medisin.uio.no (H.B.B.)

$\dagger$ Deceased on 18 October 2009.

* Author to whom correspondence should be addressed; E-Mail: arne.boyum@medisin.uio.no; Tel.: +47 22851409; Fax: +47 22851249.

Received: 12 December 2009 / Accepted: 18 January 2010 / Published: 20 January 2010

\begin{abstract}
Inflammatory mediators trigger polymorphonuclear neutrophils (PMN) to produce reactive oxygen species ( $\mathrm{ROS}: \mathrm{O}_{2}^{-}, \mathrm{H}_{2} \mathrm{O}_{2}, \cdot \mathrm{OH}$ ). Mediated by myeloperoxidase in $\mathrm{PMN}, \mathrm{HOCl}$ is formed, detectable in a chemiluminescence (CL) assay. We have shown that the abundant cytosolic PMN protein calprotectin (S100A8/A9) similarly elicits CL in response to $\mathrm{H}_{2} \mathrm{O}_{2}$ in a cell-free system. Myeloperoxidase and calprotectin worked synergistically. Calprotectin-induced CL increased, whereas myeloperoxidase-triggered $\mathrm{CL}$ decreased with $\mathrm{pH}>7.5$. Myeloperoxidase needed $\mathrm{NaCl}$ for $\mathrm{CL}$, calprotectin did not. 4-hydroxybenzoic acid, binding $\cdot \mathrm{OH}$, almost abrogated calprotectin $\mathrm{CL}$, but moderately increased myeloperoxidase activity. The combination of native calprotectin, or recombinant S100A8/A9 proteins, with $\mathrm{NaOCl}$ markedly enhanced CL. NaOCl may be the synergistic link between myeloperoxidase and calprotectin. Surprisingly- and unexplained-
\end{abstract}


at higher concentration of S100A9 the stimulation vanished, suggesting a switch from pro-oxidant to anti-oxidant function. We propose that the $\cdot \mathrm{OH}$ is predominant in ROS production by calprotectin, a function not described before.

Keywords: chemiluminescence; polymorphonuclear neutrophils (PMN); myeloperoxidase; calprotectin; S100A8/A9; NaOCl; albumin; cytidine deaminase; 4-hydroxy-benzoic acid

\section{Introduction}

During phagocytosis of microorganisms polymorphonuclear neutrophils (PMN) rapidly and heavily increase oxygen consumption, mainly due to production of reactive oxygen species (ROS) [1]. This respiratory burst, which can be triggered from various surface receptors of PMN, can be measured as chemiluminescence (CL) in a luminometer. During ROS formation oxygen is reduced to superoxide $\left(\mathrm{O}_{2}{ }^{-}\right)$, which is converted to $\mathrm{H}_{2} \mathrm{O}_{2}$, either spontaneously or by the catalytic action of superoxide dismutase. Further reactions generate two potent reaction products, hydroxyl radicals $(\cdot \mathrm{OH})$, in the presence of iron, and hypochlorous acid $(\mathrm{HOCl})$, catalysed by myeloperoxidase (MPO) and chloride ions. In neutrophils approximately $30-40 \%$ of the detectable superoxide is converted to $\mathrm{HOCl}$ [2]. Unfortunately, ROS not only kill microbes, but they can also cause tissue damage by modifying DNA, lipids, proteins, and carbohydrates [1,3]. It is therefore necessary to control the cellular redox state to balance beneficial and harmful effects of these agents.

MPO, the catalyst of $\mathrm{HOCl}$ production, may amount to 5\% [4] of total protein in PMN, being mostly present in the primary granules [5]. We wanted to examine whether the most abundant cytosolic PMN protein, calprotectin, might interact with this important generator of ROS. Another cytosolic protein, cytidine deaminase, was chosen as control.

Calprotectin [6,7] is a heterodimer composed of 11 and $13 \mathrm{kDa}$ subunits, whose precise functions are still unknown. It belongs to the $\mathrm{S} 100$ [8] (S100A8/S100A9) protein family [9]. This calciumbinding protein with antimicrobial activity constitutes about 5\% of total PMN protein [7] and as much as $40-50 \%$ of cytosolic protein [10]. Calprotectin takes part in inflammatory processes [11], but it is not known how. Increased concentrations of calprotectin, extracellularly in various body fluids and probably released by PMN, are found in many types of infectious diseases [7].

Cytidine deaminase has, apart from its enzyme function, a suppressive effect on hematopoietic colony formation in vitro $[12,13]$. One granulocyte contains approximately $0.1 \mathrm{pg}$ cytidine deaminase [14], which may correspond to $0.3-1.0 \%$ of cellular protein extractable with water. Plasma concentrations of cytidine deaminase increase markedly in response to physical stress [14] and during sepsis [15].

Since calprotectin and cytidine deaminase co-exist with MPO in PMN, it is difficult to evaluate their individual contribution to ROS production in intact cells-if any. Therefore, we used the MPO- $\mathrm{H}_{2} \mathrm{O}_{2}$-system as a cell-free model of the respiratory burst [16,17], to examine the effects of added calprotectin or cytidine deaminase. Luminol was used as effective amplifier of MPO-dependent CL. We compared ROS-induction by MPO and calprotectin acting alone, but also together and by 
varying $\mathrm{pH}$, temperature, and several putatively enhancing or inhibiting ingredients. The results were compared with responses elicited by intact PMN and macrophages.

\section{Results}

\subsection{Basic response pattern}

The cell-free $\mathrm{H}_{2} \mathrm{O}_{2}$-MPO-Cl-luminol system was designed to model the respiratory burst. The CL peaked within a few minutes, then tapered off for the next 23 minutes of recording (Figure 1a). Calprotectin increased $(\mathrm{p}<0.05)$ CL (Figure 1b), whereas cytidine deaminase inhibited it already after one minute $(\mathrm{p}<0.05)$.

Figure 1. Luminol-dependent chemiluminescence (CL) of myeloperoxidase (MPO) is modified by addition of calprotectin, cytidine deaminase (CDD), and human serum albumin (HSA). CL was measured in duplicate every minute (not all values plotted) for 25 minutes at $\mathrm{pH}$ 7.4. (a): Time-response pattern obtained with a mixture of $\mathrm{H}_{2} \mathrm{O}_{2}$ $(500 \mu \mathrm{M})+\operatorname{MPO}(0.1 \mu \mathrm{g} / \mathrm{mL})$ in HBBS $(120-130 \mathrm{mM} \mathrm{NaCl}), \pm \mathrm{CDD}(3.2 \mu \mathrm{g} / \mathrm{mL})$. The CL was measured as relative light units. Mean values with SEM (sometimes hidden in the symbols) from five experiments. (b): CL was induced as described in (a), and the effects of calprotectin, CDD and HSA are presented as area under the 0-25 minutes curve (CL-AUC). The values are given in per cent of MPO alone control. The combined effect of MPO and calprotectin was measured in duplicate in four experiments, of cytidine deaminase and HSA in triplicate in three parallel experiments. The percent inhibition by CDD gave almost identical results (three experiments) when carried out at room temperature and $37^{\circ} \mathrm{C}$. (c): CL-AUC, dose-response curve for calprotectin (without MPO); $\mathrm{H}_{2} \mathrm{O}_{2} 500 \mu \mathrm{M}, \mathrm{pH}$ 7.8. Two experiments.

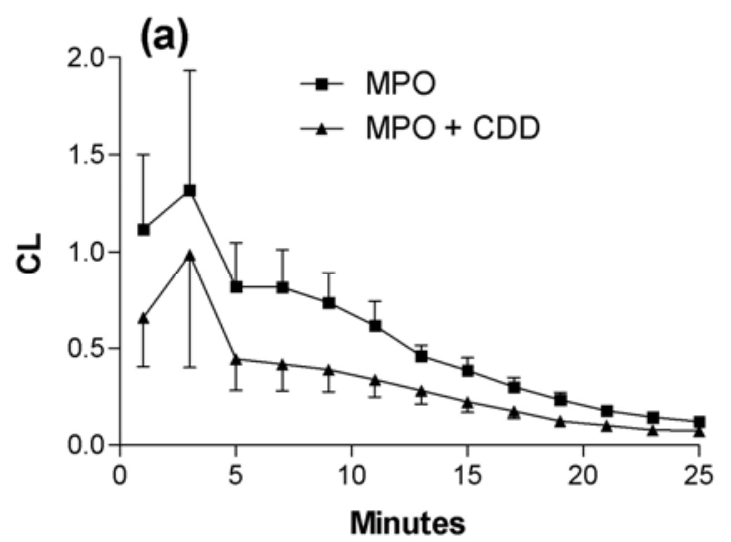


Figure 1. Cont.
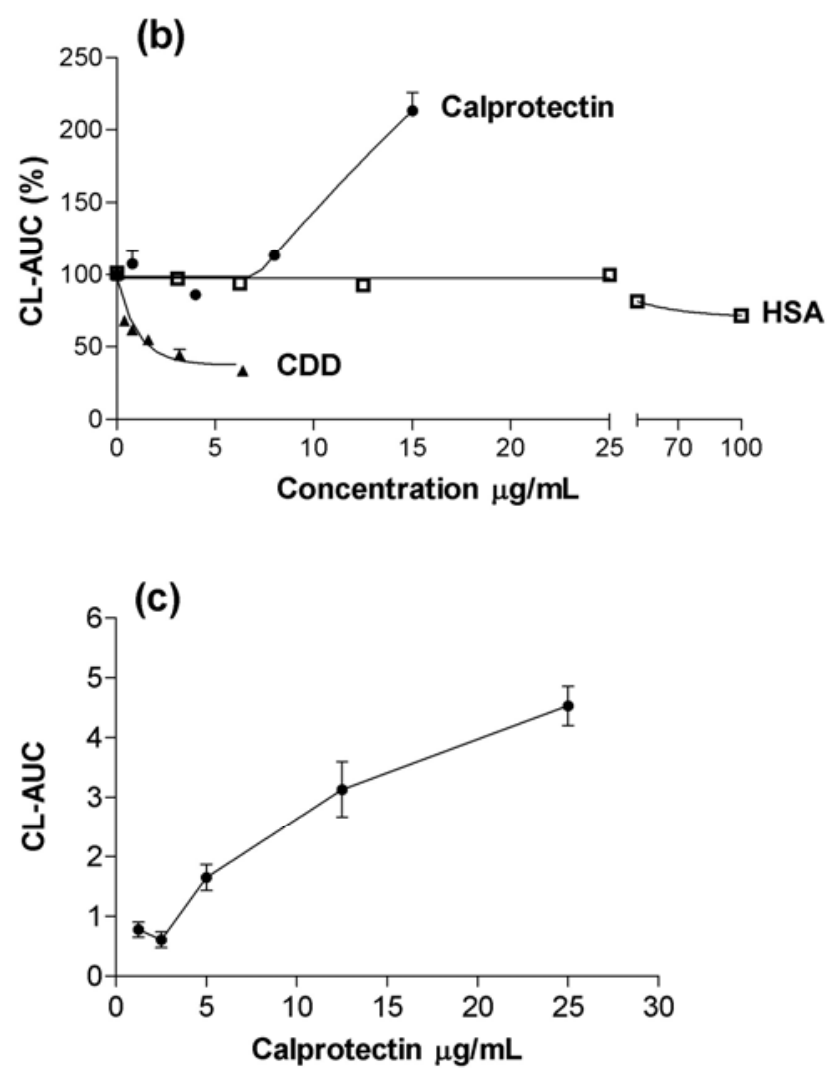

In the four experiments depicted in Figure $1 \mathrm{MPO}(0.1-0.3 \mu \mathrm{g} / \mathrm{mL})$ and calprotectin $(16 \mu \mathrm{g} / \mathrm{mL})$ in combination had an additive effect on light emission $(\mathrm{p}<0.05)$. A moderate increase $(21 \%)$ was also observed for $8.0 \mu \mathrm{g} / \mathrm{mL}$ calprotectin $(\mathrm{p}<0.05)$, provided that the data for only the first 10 minutes were used. For a total of nine experiments the effect was not only additive $(p<0.001)$, but also potentiated synergistic $(\mathrm{p}<0.01)$; the average CL integrals being MPO 8.9, calprotectin 4.8 and MPO + calprotectin 19.1. Even though stimulation by calprotectin varied considerably (see below), it was not significantly affected by addition of, or preincubation with, calcium (1-2 mM). It is noteworthy that PMN may contain $>10.000 \mu \mathrm{g} / \mathrm{mL}$ calprotectin [7].

Dose-response experiments showed that the CL was enhanced more than linearly with increased concentrations of MPO $(0.1-0.4 \mu \mathrm{g} / \mathrm{mL}$ ), and at high activity of MPO (not shown) the inhibitory effect of a constant cytidine deaminase concentration $(3.2 \mu \mathrm{g} / \mathrm{mL})$ was reduced $(\mathrm{p}<0.01)$. On the other hand, with a constant MPO concentration, cytidine deaminase exerted increasing inhibition in the dose range $0.8-6.4 \mu \mathrm{g} / \mathrm{mL}$ (Figure $1 \mathrm{~b}$ ). The PMN concentration of cytidine deaminase has been measured to be $100-200 \mu \mathrm{g} / \mathrm{mL}[14]$.

In the same molar or mass concentration ranges used for cytidine deaminase and calprotectin, control human serum albumin (HSA) had no effect on MPO-CL, but inhibited the response at concentrations $\geq 100 \mu \mathrm{g} / \mathrm{mL}(\mathrm{p}<0.05)$. CL was not induced with MPO or calprotectin when luminol was replaced by lucigenin $(0.1 \mathrm{mM})$, which is supposed to mostly reflect superoxide formation. The calprotectin had no detectable peroxidase activity in the ECL assay. 
Figure 2. The effect of $\mathrm{pH}$ (a-e) on $\mathrm{CL}$ elicited by $\mathrm{H}_{2} \mathrm{O}_{2}$-stimulated $(500 \mu \mathrm{M}) \mathrm{MPO}$ $(0.1 \mu \mathrm{g} / \mathrm{mL})$ and calprotectin $(\mathrm{CP} ; 8 \mu \mathrm{g} / \mathrm{mL})$; comparison with PMA-evoked cell responses (in phosphate buffers, $80-85 \mathrm{mM}$, osmolality $290 \mathrm{mOsm} / \mathrm{kg}$ ). (a-c): Triplicate measurements of MPO- and CP-induced CL in two experiments with $\mathrm{pH}$ 7.0, 7.5 and 7.9 show the kinetics of the response during 30 minutes and (d) gives the corresponding AUC (e): CL elicited by MPO and CP in Dulbecco's phosphate-buffered ( $\sim 6 \mathrm{mM})$ saline ( $\sim 105 \mathrm{mM} \mathrm{NaCl})-\mathrm{pH}$ adjusted with $\mathrm{NaOH}$ (f): CL elicited by PMA-stimulated human granulocytes $\left(2 \times 10^{5} /\right.$ well $)$. $(\mathrm{g})$ : rat granulocytes $\left(1.5 \times 10^{5} /\right.$ well $)$ and $(\mathrm{h})$ : rat peritoneal cells (PC; $3 \times 10^{5} /$ well). PMA was $10^{-7} \mathrm{M}$ for human cells and $4 \times 10^{-7} \mathrm{M}$ for rat cells. Mean values from two experiments. The graphs (f, g, h) show CL responses for three different $\mathrm{pH}$ values and the integrals (AUC) are shown in (i), in per cent of integrals obtained with $\mathrm{pH}$ 7.5. The $\mathrm{pH}$ (except e) was adjusted by appropriate portions of $\mathrm{Na}_{2} \mathrm{HPO}_{4}$ and $\mathrm{NaH}_{2} \mathrm{PO}_{4}(85 \mathrm{mM}$ phosphate, $63 \mathrm{mM} \mathrm{NaCl})$.

(a)

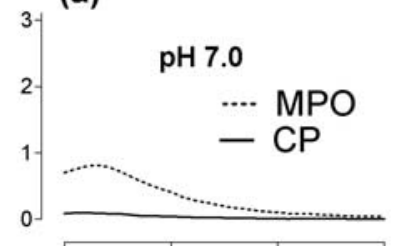

(b)

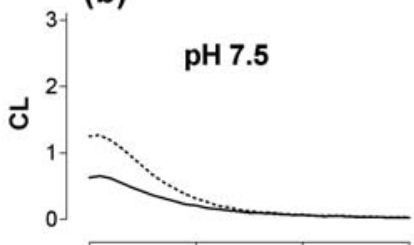

(c)
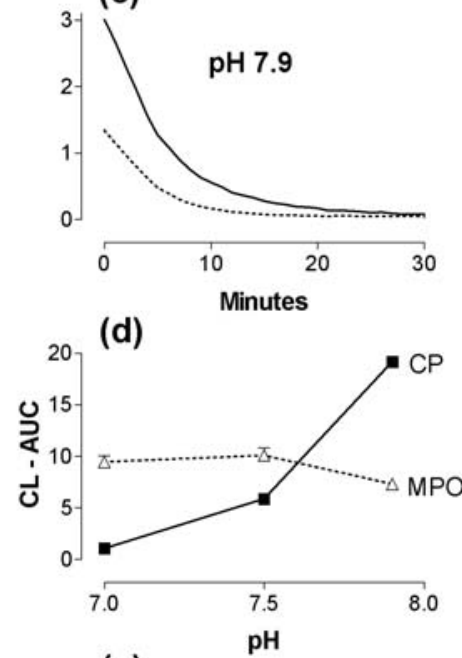

(e)

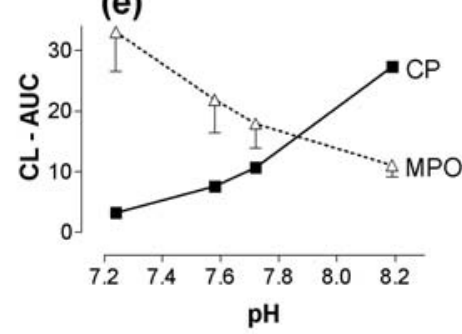

(f)
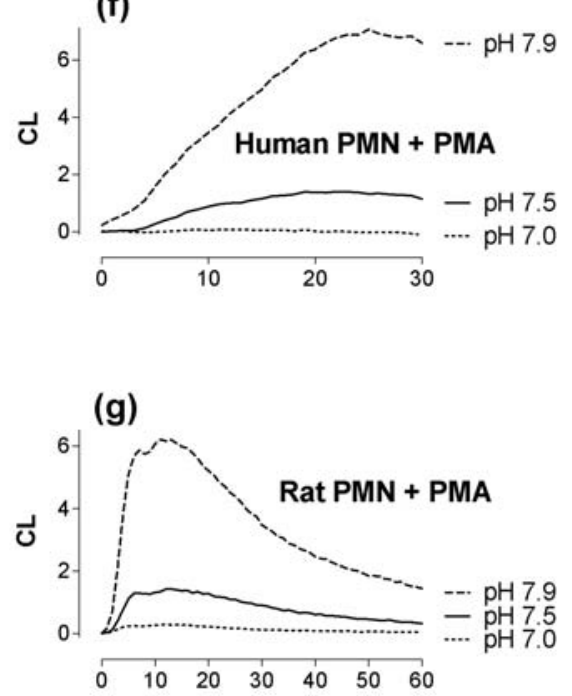

(h)

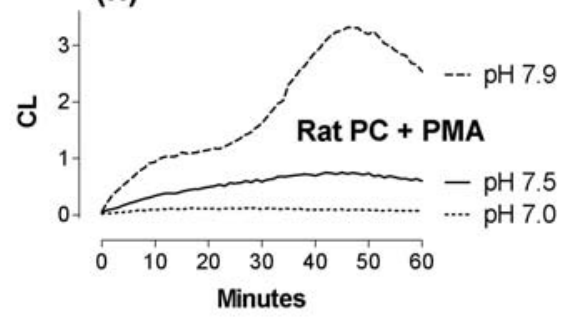

(i)

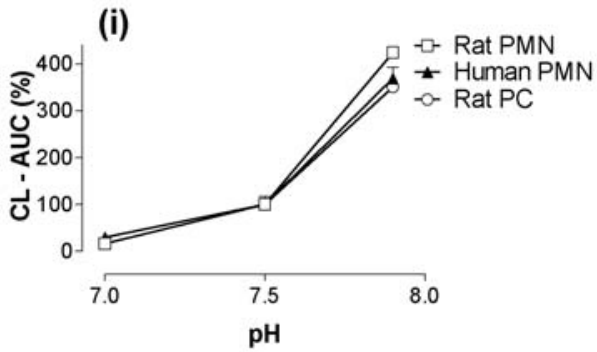


2.2. The effect of $\mathrm{pH}$ changes on MPO- and calprotectin-chemiluminescence, and responses by granulocytes and peritoneal cells

As demonstrated for the first time here, calprotectin itself can induce CL. However, the activity of calprotectin was lower than for MPO, and we wanted to test if it could be enhanced by modifying the experimental procedure. At first we tested $\mathrm{pH}$ changes and found that the response (AUC) to calprotectin $(8 \mu \mathrm{g} / \mathrm{mL})$ was increased from 1 to $19(\mathrm{p}<0.001)$ and the MPO-dependent response decreased (AUC from 10 to $7.3, \mathrm{p}<0.01$ ) along with elevation of $\mathrm{pH}$ from 7.0 to 7.9 (Figures $2 \mathrm{a}-\mathrm{d}$ ). In four new experiments these results were confirmed with another buffer (Dulbecco's phosphatebuffered saline), and calprotectin luminescence could be markedly enhanced by a $\mathrm{pH}$ increase from 7.1 to 7.4. In additional tests we found that $2-4 \mu \mathrm{g} / \mathrm{mL}$ of calprotectin, with $\mathrm{pH} 7.9$ and $60-500 \mu \mathrm{M} \mathrm{H}_{2} \mathrm{O}_{2}$ was appropriate for routine use.

Controls, relevant according to molar and mass concentrations, with HSA (up to $1000 \mu \mathrm{g} / \mathrm{mL}$ ) or human immunoglobulin $(20 \mu \mathrm{g} / \mathrm{mL}$ ) yielded CL (AUC) of $\sim 1$ or less (not shown). A pH-dependent pattern was also observed for CL elicited by PMA-stimulated human granulocytes, rat granulocytes, and rat peritoneal cells (Figure $2 \mathrm{f}-\mathrm{h}$ ). This response (Figure $2 \mathrm{i}$ ) resembled the $\mathrm{pH}$ dependency of the calprotectin-response more than that of the MPO-response (Figures 2d, e).

This pattern was confirmed when $\mathrm{H}_{2} \mathrm{O}_{2}$ instead of PMA was used as stimulator of human PMN (Figure 3), thereby presumably bypassing the contribution by phagocyte NADPH oxidase. This $\mathrm{H}_{2} \mathrm{O}_{2}$ response was almost aborted by azide $(1 \mathrm{mM})$ at $\mathrm{pH}$ 6.1, and the 12-minute response was consistently reduced at $\mathrm{pH}$ 6.9-7.8, probably reflecting an inhibitory effect of azide on the heme enzyme (MPO). However, as $\mathrm{pH}$ increased, the response in the azide groups was changed (Figure $3 \mathrm{a}-\mathrm{d}$ ), and the 60-minute CL integral (at pH 7.4 and 7.8) was increased above control without azide (Figure 3e, $\mathrm{p}<0.01$ ). With $20000 \mathrm{PMN} /$ well (Figure $3 \mathrm{f}$ ), we found that $16 \mu \mathrm{M}$ of $\mathrm{H}_{2} \mathrm{O}_{2}$ was sufficient to yield a significant $(\mathrm{p}<0.05)$ response.

Figure 3. The effect of $\mathrm{pH}$ on kinetics of $\mathrm{H}_{2} \mathrm{O}_{2}$-mediated $(500 \mu \mathrm{M})$ CL-responses in human PMN $\left(2 \times 10^{5}\right.$ well) monitored for 60 minutes in phosphate buffer, without and with $1 \mathrm{mM} \mathrm{Na-azide} \mathrm{(a-d).} \mathrm{Triplicate} \mathrm{measurements} \mathrm{from} \mathrm{three} \mathrm{experiments.} \mathrm{(e)} \mathrm{gives} \mathrm{the}$ 60-minute integrals (AUC) as a function of $\mathrm{pH}$. (f): Dose-response curve for $\mathrm{H}_{2} \mathrm{O}_{2}$ when human PMN $\left(2 \times 10^{4} /\right.$ well $)$ were examined for 30 minutes in a buffer with $\mathrm{pH} 7.8$. Mean values from three experiments in per cent of CL-AUC with $500 \mu \mathrm{M}$. Note different scales on $\mathrm{Y}$ axes (a-d).
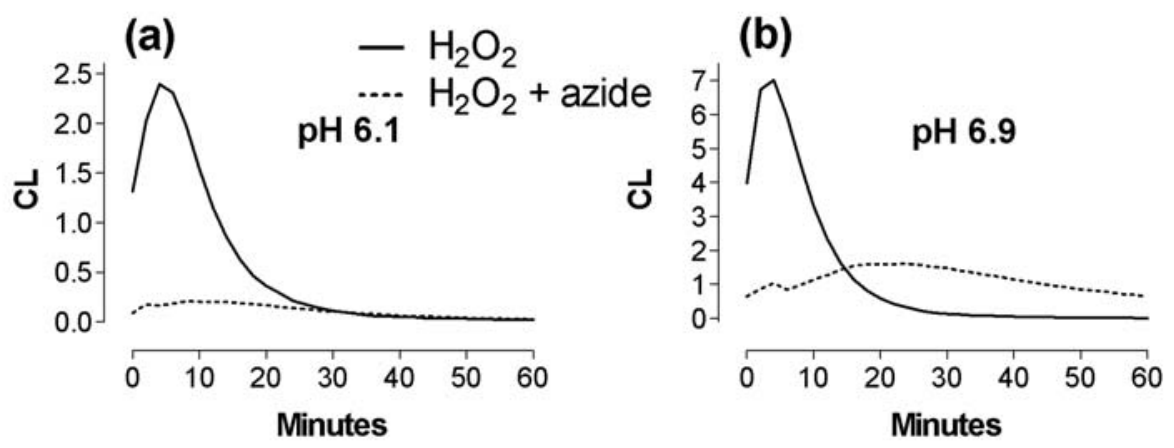
Figure 3. Cont.
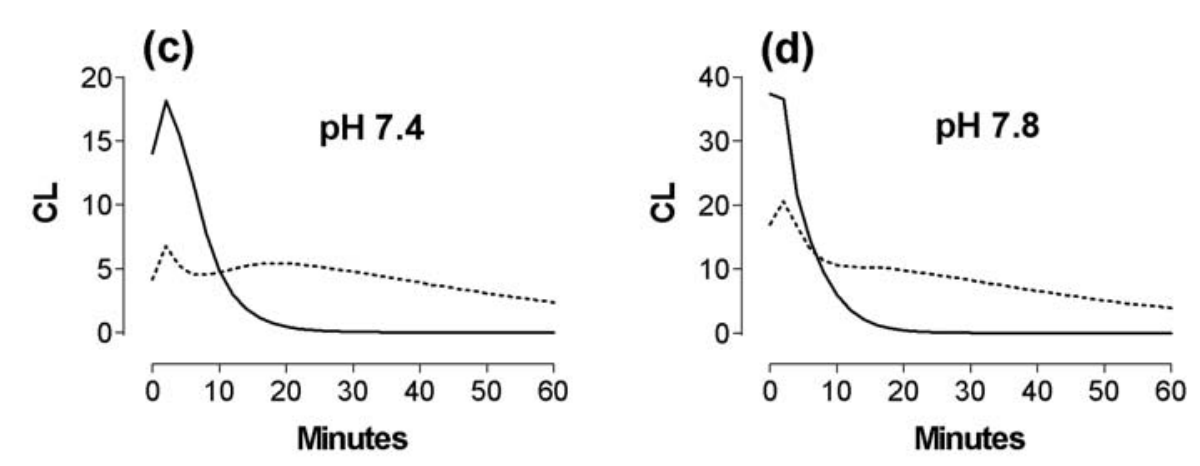

(e)
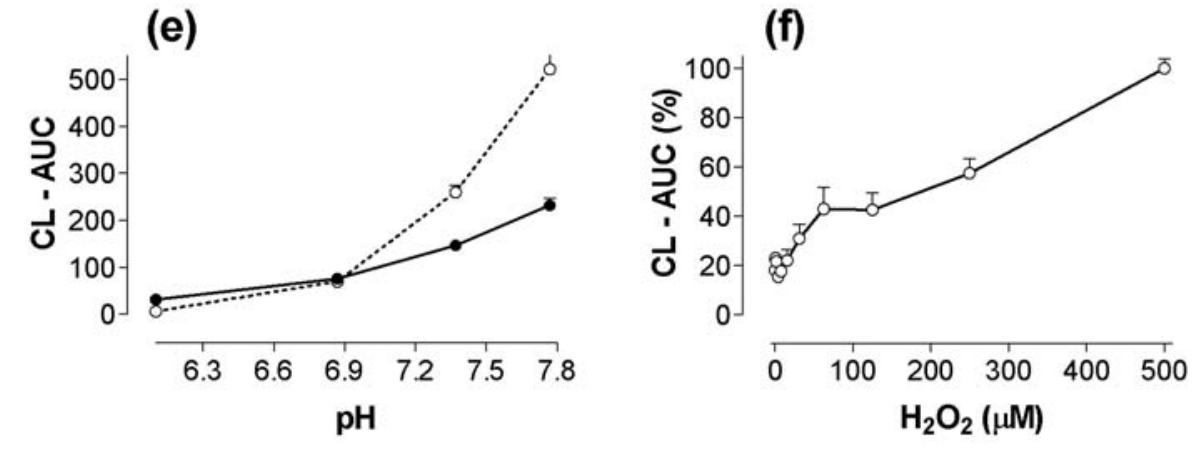

2.3. $\mathrm{CL}$ responses of calprotectin and $\mathrm{MPO}$ to $\mathrm{H}_{2} \mathrm{O}_{2}$, azide, $\mathrm{NaCl}$, melatonin, and cysteine supplements to the reaction mixtures

We also wanted to compare responses of MPO and calprotectin to different reactants, some of them known to affect MPO. The responses of MPO and calprotectin to increasing concentrations of $\mathrm{H}_{2} \mathrm{O}_{2}$ were very different (Figure $4 \mathrm{a}$ ), even though both agents showed $\mathrm{H}_{2} \mathrm{O}_{2}$-dependency. $\mathrm{H}_{2} \mathrm{O}_{2}(500 \mu \mathrm{M})+$ luminol, alone, yielded a slight response (AUC $\left.\sim 0.9\right)$ only at high pH (7.8). MPO was much more sensitive than calprotectin to the inhibitory effect of azide (Figure $4 \mathrm{~b}$ ). In fact, there was a slight stimulation of calprotectin- $\mathrm{H}_{2} \mathrm{O}_{2}-\mathrm{CL}$ at $0.02-0.1 \mathrm{mM}$ azide $(\mathrm{p}<0.05)$. Calprotectin- $\mathrm{H}_{2} \mathrm{O}_{2}-$ $\mathrm{CL}$ was independent of the presence of $\mathrm{NaCl}$, whereas $\mathrm{MPO}-\mathrm{H}_{2} \mathrm{O}_{2}-\mathrm{CL}$ required a high $\mathrm{NaCl}$ concentration (Figure 4c), presumably for $\mathrm{HOCl}$ production. The response pattern was similar for inhibition of MPO and calprotectin by added cysteine and melatonin - added as anti-oxidants [18] with MPO the more sensitive $(\mathrm{p}<0.01)$ (Figures $4 \mathrm{~d}$, e). 
Figure 4. Comparative studies of MPO and calprotectin. Triplicate measurements during 30 minutes. (a): Dose-response of $\mathrm{H}_{2} \mathrm{O}_{2}$-induced MPO-CL and calprotectin-CL. The values are given in per cent (with SEM) of groups with $500 \mu \mathrm{M} \mathrm{H}_{2} \mathrm{O}_{2}$. Phosphate-buffer with $\mathrm{pH}$ 7.8. Mean values from two experiments. (b): Dose-response of Na-azide. MPO $\left(0.16 \mu \mathrm{g} / \mathrm{mL}, \sim 1.3 \times 10^{-8} \mathrm{M}\right)$. Calprotectin $\left(8 \mu \mathrm{g} / \mathrm{mL}, \sim 0.4 \times 10^{-6} \mathrm{M}\right)$. Phosphate-buffered saline, $\mathrm{pH}$ 7.4. The values from two experiments are given in per cent of controls $( \pm \mathrm{SEM})$ without azide. (c) The effect of $\mathrm{NaCl}$ on luminol-dependent MPO-CL and calprotectin-CL. MPO $(0.1 \mu \mathrm{g} / \mathrm{mL}, \mathrm{pH} 7.4)$. Calprotectin $(4 \mu \mathrm{g} / \mathrm{mL}, \mathrm{pH} 7.8)$. The calprotectin had been dialysed against a NaCl-free solution. The values are given in per cent of groups with $100 \mathrm{mM} \mathrm{NaCl}$. Five experiments with and without $100 \mathrm{mM} \mathrm{NaCl}$. (d): Dose-response of cysteine on MPO-CL and calprotectin-CL (2 experiments). (e): Dose-response of melatonin on MPO-CL and calprotectin-CL (2 experiments). MPO $(0.05 \mu \mathrm{g} / \mathrm{mL}, \mathrm{pH} 7.4)$, calprotectin $(4 \mu \mathrm{g} / \mathrm{mL}, \mathrm{pH} 7.8)$ in (d) and (e).

(a)

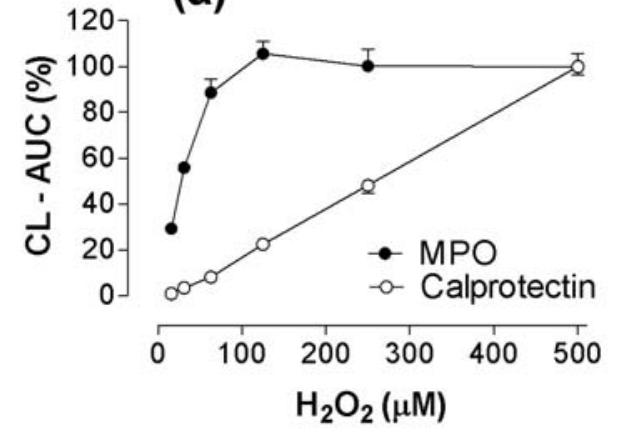

(c)

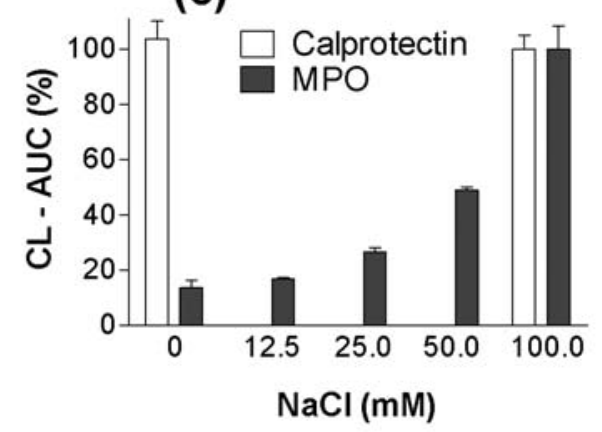

(e)

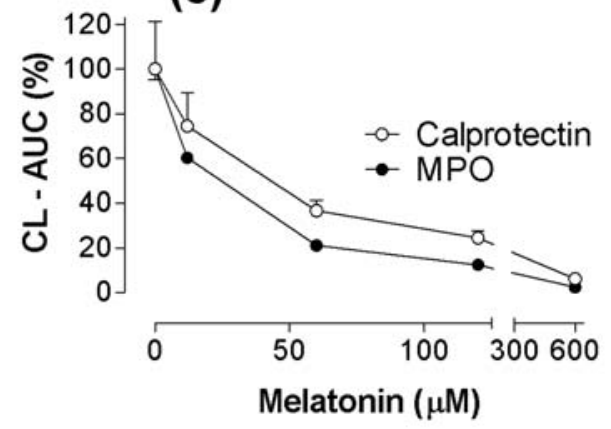

(b)

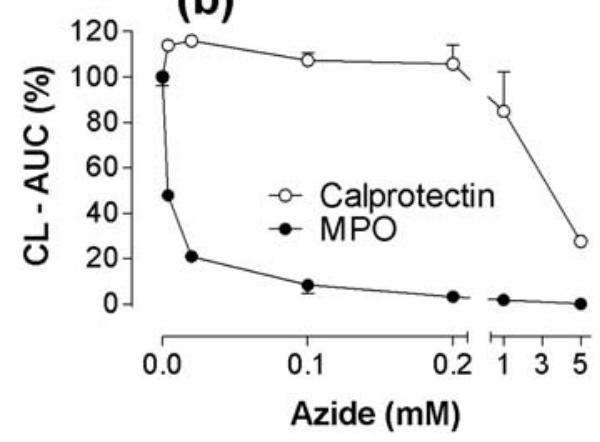

(d)

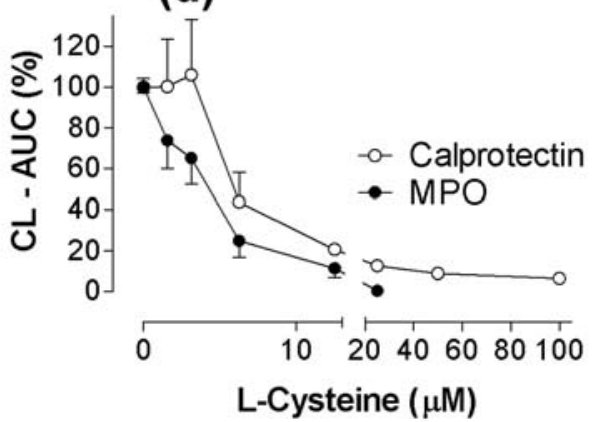




\subsection{The combined effect of calprotectin and $\mathrm{NaOCl}$}

The combination of calprotectin $(4 \mu \mathrm{g} / \mathrm{mL})$ and $\mathrm{NaOCl}(20 \mu \mathrm{M})$ strongly enhanced $\mathrm{CL}$ in the presence of $\mathrm{H}_{2} \mathrm{O}_{2}$ (Figure 5), possibly caused by oxidation of calprotectin by $\mathrm{NaOCl}$ [19]. Since $\mathrm{HOCl}$ is the end product in the MPO-system, this finding may explain the synergy observed by combining MPO and calprotectin (Figure 1). $\mathrm{NaOCl}$ itself may generate significant CL, but high background values are largely avoided at low concentrations of $\mathrm{H}_{2} \mathrm{O}_{2}$ (Figure 5). Noteworthy, it was necessary to incubate the mixture of calprotectin and $\mathrm{NaOCl}$ for 17-20 minutes at room temperature in these experiments, before the CL reaction could be initiated by adding luminol and $\mathrm{H}_{2} \mathrm{O}_{2}$ and enhancement demonstrated [19]. Dose-response experiments showed that a calprotectin concentration of $0.5-1.0 \mu \mathrm{g} / \mathrm{mL}$ was sufficient, when combined with $\mathrm{NaOCl}$ and $\mathrm{H}_{2} \mathrm{O}_{2}(>16 \mu \mathrm{M})$, to induce a significant $\mathrm{CL}$ response, whereas no response was observed in the absence of $\mathrm{NaOCl}$.

Figure 5. Luminol-enhanced combined effect of calprotectin (CP; $4 \mu \mathrm{g} / \mathrm{mL})$ and $\mathrm{NaOCl}$ $(20 \mu \mathrm{M})$ in phosphate buffer with $\mathrm{pH}$ 7.8. $\mathrm{CP}$ and $\mathrm{NaOCl}$ were incubated at room temperature for 17 minutes [19] before luminol and $\mathrm{H}_{2} \mathrm{O}_{2}$ were added to initiate ROS formation. (a): Time-course of CL responses recorded during 30 minutes with $63 \mu \mathrm{M} \mathrm{H}_{2} \mathrm{O}_{2}$ (b): Effect of increasing concentrations of $\mathrm{H}_{2} \mathrm{O}_{2}$ on $\mathrm{CL}$ induced by $\mathrm{NaOCl}, \mathrm{CP}$, and $\mathrm{NaOCl}+\mathrm{CP}$. Two experiments.

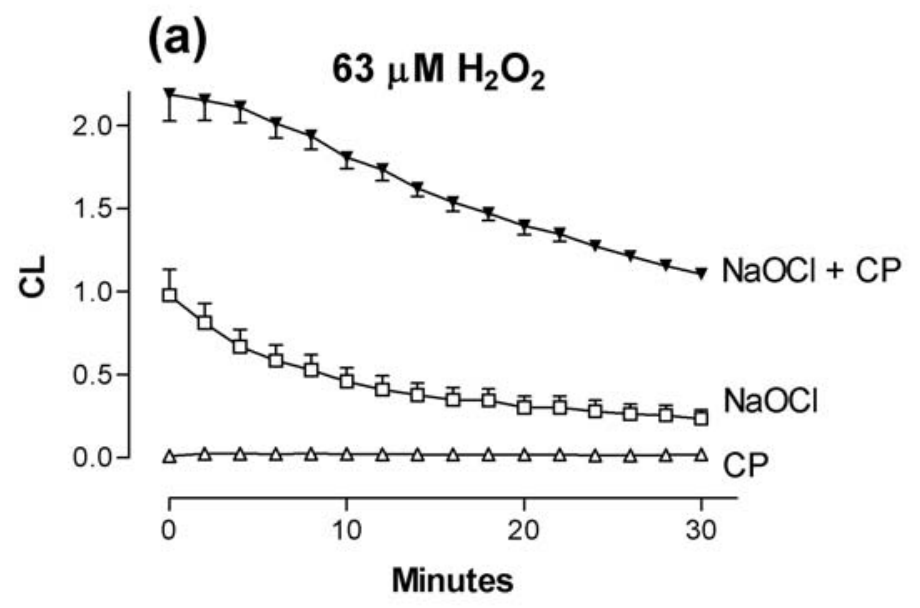

(b)

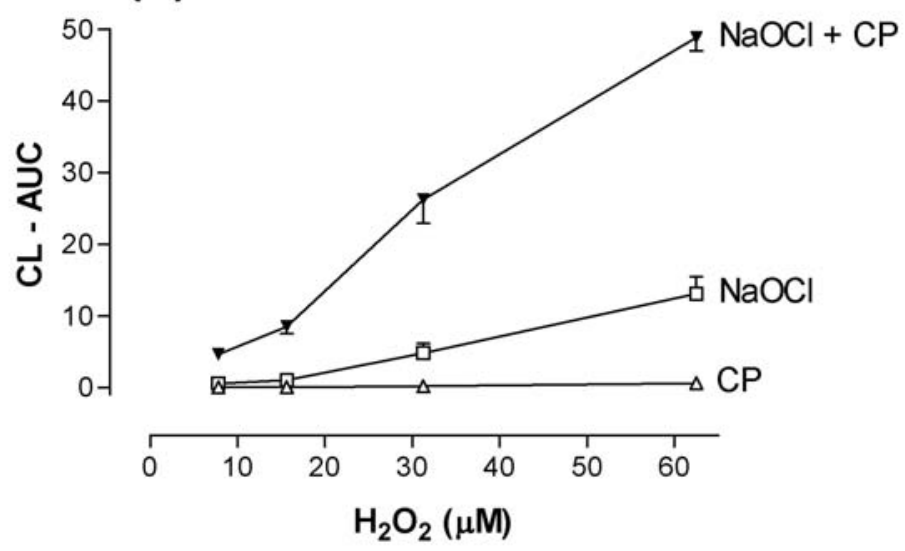




\subsection{Recombinant S100A8 (A8) and S100A9 (A9)}

A8 remained a monomer in solution while A9 formed a dimer as well (Figure 6), but to a different extent in different batches. Dimerization apparently enhanced the capacity to generate CL in the presence of $\mathrm{H}_{2} \mathrm{O}_{2}$ (data not shown).

Figure 6. Recombinant S100A8 and S100A9, and calprotectin (CP), were separated on SD-PAGE prior to SYPRO Ruby staining. A9 tended to form homodimers, whereas with the mixture of leucocyte-derived A8 and A9 (CP), the proteins migrated as monomers, homodimers or heterodimers. Standard (St) with molecular weight markers $(6,14,17,28)$ in $\mathrm{kDa}$.

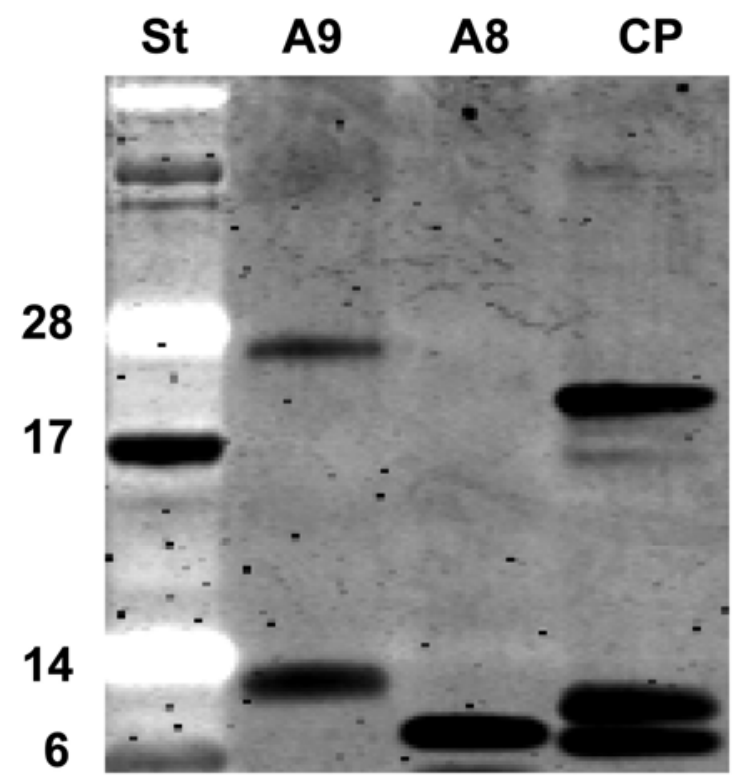

The activity of A9 (Figures 7a, b) clearly depended upon both protein concentration $(5-40 \mu \mathrm{g} / \mathrm{mL})$ and $\mathrm{pH}$, as did A8, which produced less CL (not shown). Mercaptoethanol-treated A9 elicited no detectable CL. A9 with $\mathrm{NaOCl}+32 \mu \mathrm{M} \mathrm{H}_{2} \mathrm{O}_{2}$ gave a marked pH-dependent CL-response (Figure 7c). An even stronger response was observed with $63 \mu \mathrm{M} \mathrm{H} \mathrm{H}_{2} \mathrm{O}_{2}$ (Figure 7d). However, increasing concentrations above $3.6 \mu \mathrm{g} / \mathrm{mL}$ led to a gradual decrease of the $\mathrm{CL}$, in contrast to the set-up without $\mathrm{NaOCl}$ included (Figure 7a). Similarly, $\mathrm{HSA}+\mathrm{NaOCl}$ evoked a slight increase of CL up to $25 \mu \mathrm{g} / \mathrm{mL}$ albumin, declining to no response at $200-1,000 \mu \mathrm{g} / \mathrm{mL}$. HSA without $\mathrm{NaOCl}$ did not cause any CL (2.5 to $1,000 \mu \mathrm{g} / \mathrm{mL}$ ). At $\mathrm{pH} 7.8$ similar responses were observed for A8 and A9 when combined with $\mathrm{NaOCl}$ (not shown). The activity of mercaptoethanol-exposed A9 was also restored by $\mathrm{NaOCl}$. 
Figure 7. Dose-response curves and $\mathrm{pH}$-dependency for $\mathrm{CL}$ generated by A9 and HSA in a $\mathrm{H}_{2} \mathrm{O}_{2}$-luminol system. (a) shows $\mathrm{CL}$ at different concentrations of $\mathrm{A} 9$ ( $\mathrm{pH}$ 7.9); (b) shows $\mathrm{CL}$ induced by $\mathrm{A} 9(20 \mu \mathrm{g} / \mathrm{mL})$ at three different $\mathrm{pH}$. The $\mathrm{H}_{2} \mathrm{O}_{2}$ concentration $(\mathrm{a}, \mathrm{b})$ was $500 \mu \mathrm{M}$. (c) gives dose-response curves for $\mathrm{A} 9$ at two different $\mathrm{pH}$ values; $32 \mu \mathrm{M} \mathrm{H}_{2} \mathrm{O}_{2}$. (d) shows $\mathrm{CL}$ induced by $\mathrm{A} 9+\mathrm{NaOCl}(20 \mu \mathrm{M})$, or $\mathrm{HSA}+\mathrm{NaOCl}(20 \mu \mathrm{M})$. The effect of 4-hydroxy-benzoic acid (HBA, $2 \mathrm{mM}$ ), an $\cdot \mathrm{OH}$ trapping compound, was assayed at one A9 concentration $(3.6 \mu \mathrm{g} / \mathrm{mL})$. All set-ups in (d) with $63 \mu \mathrm{M} \mathrm{H}_{2} \mathrm{O}_{2}$. Mean values from two experiments, corrected for background values in buffers. The experiments were carried out with the FLx800 luminometer at room temperature.

(a)

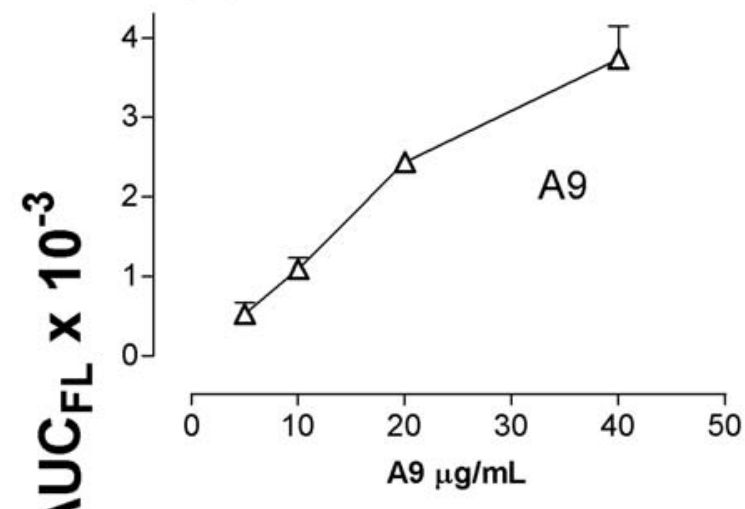

(c)

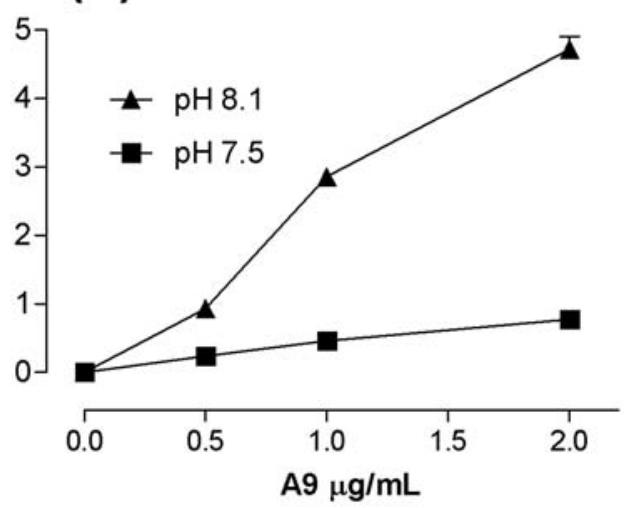

(b)

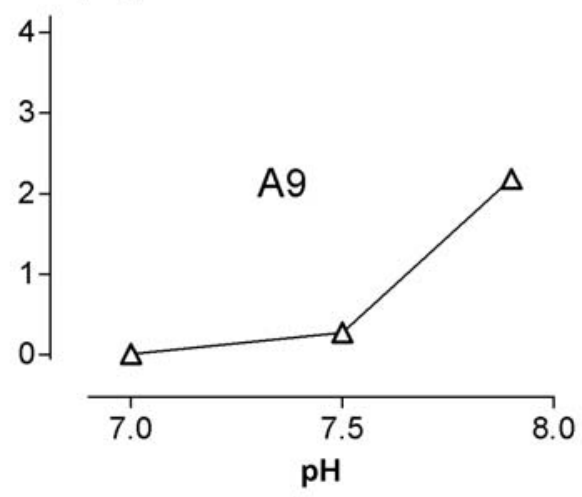

(d)

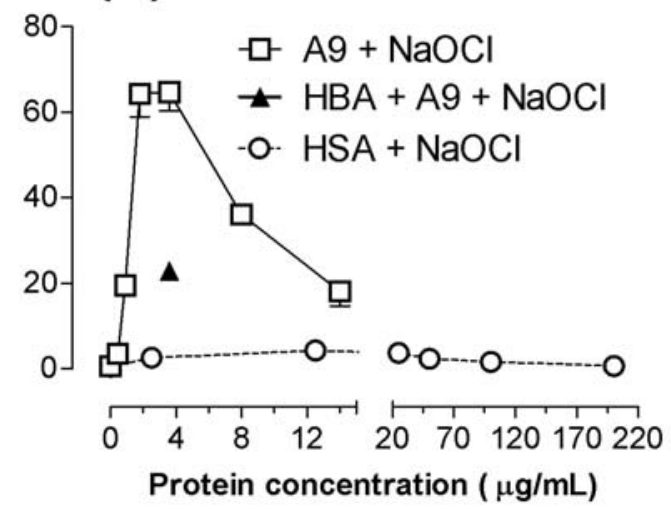

A molar ratio of 1.6-3.2 between $\mathrm{H}_{2} \mathrm{O}_{2}$ and $\mathrm{NaOCl}$ proved to be optimal for A9-induced CL. We assessed the procedure by keeping the ratio constant at 1.6 in the dose ranges of 4-64 $\mu \mathrm{M}$ for $\mathrm{H}_{2} \mathrm{O}_{2}$ and 2.5-40 $\mu \mathrm{M}$ for $\mathrm{NaOCl}$ and obtained a bell-shaped curve for A9-CL, with $1.2 \mu \mathrm{g}$ A9 per mL (Figure 8). Low background levels of the $\mathrm{NaOCl}+\mathrm{H}_{2} \mathrm{O}_{2}$ were maintained. We saw A9-CL significantly above background ( $\mathrm{p}<0.05$ ) with only $5.0 \mu \mathrm{M} \mathrm{NaOCl}+8 \mu \mathrm{M} \mathrm{H}_{2} \mathrm{O}_{2}$. These values of $\mathrm{NaOCl}$ and $\mathrm{H}_{2} \mathrm{O}_{2}$ are in the physiological range [4,20,21]. It is possible to trigger ROS formation even more by increasing the $\mathrm{H}_{2} \mathrm{O}_{2}$ concentration (with constant $\mathrm{NaOCl}$ ), but this tends to elevate the $\mathrm{NaOCl}$-induced background levels and leads to more variable responses. For routine use, 10 or $20 \mu \mathrm{M} \mathrm{NaOCl}$ and $\mathrm{H}_{2} \mathrm{O}_{2}$ in the 16-64 $\mu \mathrm{M}$ range is recommended. 
Figure 8. Chemiluminescence at constant $\mathrm{H}_{2} \mathrm{O}_{2} / \mathrm{NaOCl}$ ratio (=1.6). A9 $1.2 \mu \mathrm{g} / \mathrm{mL}$. Phosphate buffer with $\mathrm{pH}$ 7.8. Mean values with SEM from three experiments, with the FLx800 luminometer at room temperature.

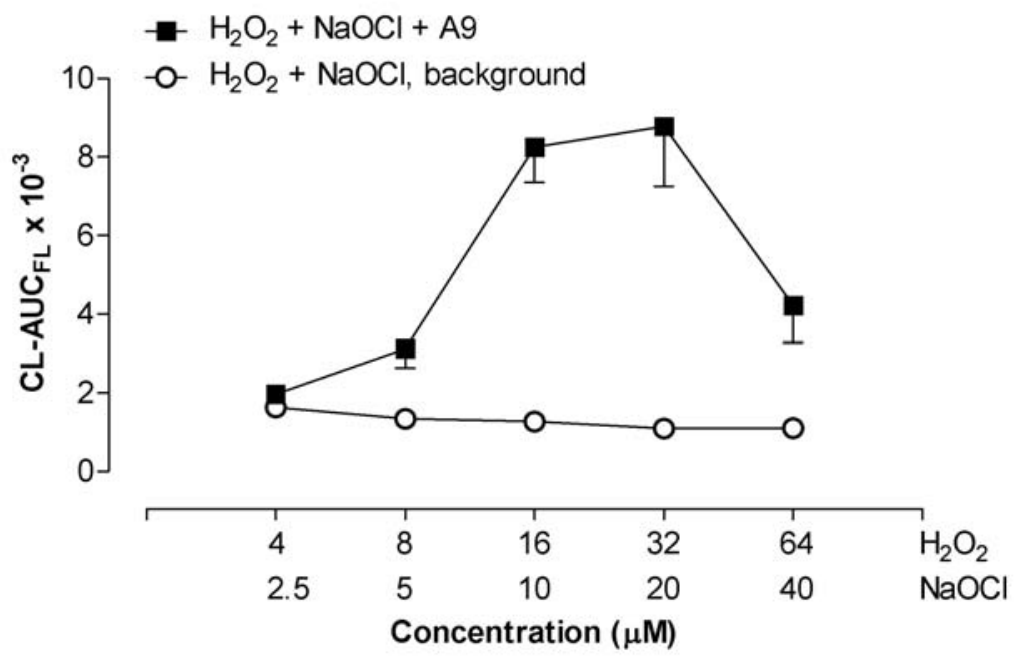

2.6. 4-hydroxy-benzoic acid (4-HBA) and L-histidine

4-HBA ( $2 \mathrm{mM})$, considered to be an agent trapping hydroxyl radicals [22-24], stimulated $(\mathrm{p}<0.05)$ the luminol- $\mathrm{H}_{2} \mathrm{O}_{2}$ - dependent $\left(500 \mu \mathrm{M} \mathrm{H}_{2} \mathrm{O}_{2}\right)$ MPO-response by $28 \%$ (five experiments). On the contrary, 4-HBA abrogated CL $(\mathrm{p}<0.05)$ by A8 $\left(500 \mu \mathrm{M} \mathrm{H}_{2} \mathrm{O}_{2}\right.$, three experiments) and A9 $(500 \mu \mathrm{M}$ $\mathrm{H}_{2} \mathrm{O}_{2}$, two experiments). In five experiments 4-HBA did not affect $\mathrm{CL}$ elicited by $\mathrm{NaOCl}$ alone, but suppressed (see Figure 7d) the intense CL generated by $\mathrm{NaOCl}+\mathrm{A} 9(1.2 \mu \mathrm{g} / \mathrm{mL})+\mathrm{H}_{2} \mathrm{O}_{2}(63 \mu \mathrm{M})$ by $65 \%(\mathrm{p}<0.001)$.

Figure 9. The effect of L-histidine, a putative singlet oxygen scavenger, on CL-integrals of MPO $(0.05 \mu \mathrm{g} / \mathrm{mL})$ and recombinant A9 $(8.0 \mu \mathrm{g} / \mathrm{mL})$, both with $500 \mu \mathrm{M} \mathrm{H}_{2} \mathrm{O}_{2}$, and A9 $(0.6 \mu \mathrm{g} / \mathrm{mL})+\mathrm{NaOCl}(20 \mu \mathrm{M})$ with $63 \mu \mathrm{M} \mathrm{H}_{2} \mathrm{O}_{2}$. Two experiments. Values in per cent of control without histidine. The results with $\mathrm{A} 9+\mathrm{NaOCl}$ were confirmed (four experiments) with the FLx800 luminometer.

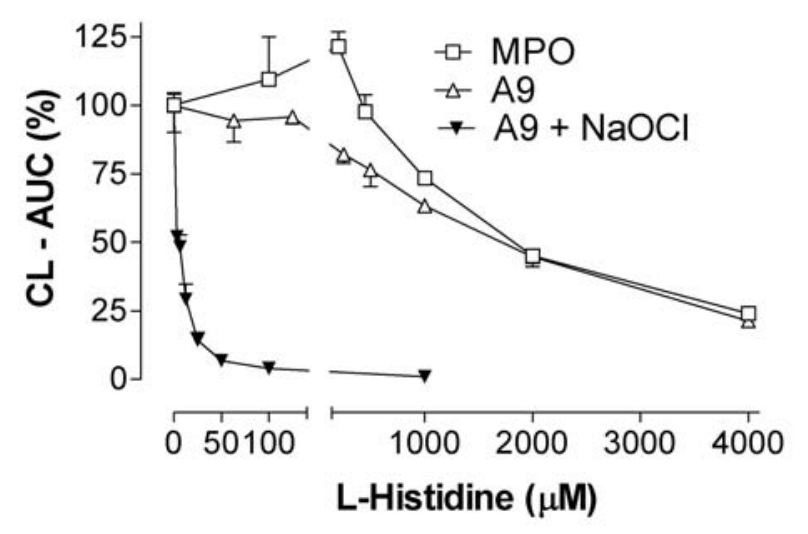


Histidine, assumed to be a singlet oxygen scavenger [25], strongly inhibited the NaOCl-increased CL induced by A9, whereas inhibition was weaker in the absence of $\mathrm{NaOCl}$, and then similar to the effect on $\mathrm{H}_{2} \mathrm{O}_{2}$-induced MPO responses (Figure 9).

\subsection{Temperature effects}

A temperature increase from 24 to $37^{\circ} \mathrm{C}$ consistently enhanced CL integrals induced by A8 and A9 in combination with $\mathrm{H}_{2} \mathrm{O}_{2}$, but only with $\mathrm{NaOCl}$ in the reaction mixture $(\mathrm{p}<0.001$; data not shown). With MPO, or A9, $+\mathrm{H}_{2} \mathrm{O}_{2}$, we observed no consistent effect of temperature change.

\subsection{The effect of iron and iron chelators}

In the absence of $\mathrm{NaOCl}$, iron ions $\left(\mathrm{FeSO}_{4}, 140 \mu \mathrm{M}\right)$ enhanced luminol- $\mathrm{H}_{2} \mathrm{O}_{2}-\mathrm{CL}$, and the effect was additive when the iron salt was combined with calprotectin. $\mathrm{FeCl}_{3}$ had a similar effect. Lower concentrations $(10-20 \mu \mathrm{M})$ stimulated only marginally. When $\mathrm{NaOCl}$ was included, there was no additional stimulatory effect of iron ions $(0.1-100 \mu \mathrm{M})$. Deferoxamine, an iron chelator $(200 \mu \mathrm{M})$, significantly (two experiments) reduced the CL-response $(\mathrm{p}<0.01)$ elicited by A8, A9, A9 + NaOCl, $\mathrm{NaOCl}$ alone, and $\mathrm{MPO}$. The strongest reduction (90\%) was observed with $\mathrm{A} 9+\mathrm{NaOCl}$, whereas an approximately $50 \%$ decline was obtained for $\mathrm{MPO}$ and $\mathrm{NaOCl}$ set-ups. The interpretation of these results is difficult since deferoxamine not only chelates iron, but may also bind and inactivate OH-radicals and possibly other ROS [26]. Taken together, the possibility exists that trace amounts of iron or other metals can activate calprotectin.

\section{Discussion}

We have shown that two major PMN cytosolic proteins, calprotectin and cytidine deaminase (CDD), had opposite effects on the in vitro luminol-amplified chemiluminescence (CL) elicited by the $\mathrm{H}_{2} \mathrm{O}_{2}-\mathrm{MPO}-\mathrm{Cl}^{-}$cell-free system. Calprotectin stimulated $\mathrm{CL}$, whereas cytidine deaminase inhibited it. Calprotectin alone, without myeloperoxidase (MPO), also triggered CL. However, at pH 7.4 this effect was detectable only at concentrations of $10-20 \mu \mathrm{g} / \mathrm{mL}(\sim 1 \mu \mathrm{M})$ or more, but $0.05-0.3 \mu \mathrm{g} / \mathrm{mL}$ $\left(0.5-3 \times 10^{-9} \mathrm{M}\right)$ was sufficient for MPO.

We interpret the results as follows: The ROS formation by MPO and calprotectin both depended upon $\mathrm{H}_{2} \mathrm{O}_{2}$. Both reactions were inhibited by L-cysteine and melatonin (Figure 4). For MPO it might be due to interaction with $\mathrm{HOCl}$, which is the CL promoting end product of the MPO reaction chain [2]. For calprotectin the inhibiting mechanism may be different. Calprotectin presumably does not generate $\mathrm{HOCl}$, since it, unlike MPO, did not need the presence of chloride for CL (Figure 4c). Other findings indicated different CL mechanisms as well: ROS generation by calprotectin or by phagocytes (granulocytes, peritoneal cells) markedly increased with increasing $\mathrm{pH}$ (Figure 2), but tended to decrease in the MPO system. Comparing calprotectin and MPO we found that these two proteins also reacted differently to 4-hydroxybenzoic acid, allegedly capable of quenching hydroxyl radicals. 
Calprotectin had no detectable peroxidase activity as measured with the ECL assay. Taken together, these findings suggest that MPO and calprotectin stimulate CL by different mechanisms.

The synergistic effect of the MPO-calprotectin combination (Figure 1b) may be due to MPO-induced $\mathrm{HOCl}$, which stimulates calprotectin activity [19]. Notably, CL in $\mathrm{H}_{2} \mathrm{O}_{2}$-stimulated human granulocytes (Figure 3) looked like a two-component response, putatively exerted by MPO and calprotectin in combination. The MPO response, which seemed to predominate at low pH (Figure 3a), was almost aborted by azide, in line with the known azide-sensitivity of MPO. At increasing $\mathrm{pH}$, a larger fraction of the total $\mathrm{CL}$ can tentatively be ascribed to the more azide-resistant calprotectin (Figure $4 b$ ).

The reduced MPO-chemiluminescence in response to a rise of $\mathrm{pH}$ contrasts some previous findings [27], but agrees with the results of Albert and Jungi [28]. The CL generated by intact PMN increased with pH (Figures 2 and 3), in accordance with previous findings [29]. Following phagocytosis there is first a $\mathrm{pH}$ rise to $\sim 7.8$ in the phagosomes, followed by a gradual decrease towards 5-6 [30], indicating that a $\mathrm{pH}$ of 7.8 might be within the physiological range. It is noteworthy that a rise of $\mathrm{pH}$ from 7 to 8 may change the configuration and increase thermal stability of calprotectin [31].

ROS detection is based upon exitation/oxidation of luminol, which relaxes to ground state by emitting light. For granulocytes, luminol amplifies a weak luminescence that also can be observed in a luminol-free medium, supposedly without changing the pattern of ROS formation [32]. The speed of occurence and size of the CL pattern can be controlled by varying the concentrations of luminol, $\mathrm{H}_{2} \mathrm{O}_{2}$, and $\mathrm{NaOCl}[33,34]$. In our study we found that $\mathrm{H}_{2} \mathrm{O}_{2}$ triggered luminol-dependent $\mathrm{ROS}$ formation by calprotectin (A8/A9) and this response was strongly enhanced by adding $\mathrm{NaOCl}$ as the fourth component. This seems to imply that calprotectin activation is linked to NADPH oxidase and MPO. In any case, a mechanism of this kind in phagocytes could probably enhance their ability to fight microorganisms. Presumably, hydroxyl radicals, generated by calprotectin, amplify the cells' microbiocidal power. If both MPO and calprotectin can normally engage, independently of each other, creating ROS in phagocytes, this might explain why most patients who lack MPO are spared from serious infections in spite of their deficiency [35].

Clearly, there are several elements that need to be evaluated to identify the physiological role of calprotectin. Calprotectin is easily oxidized by $\mathrm{NaOCl}$ [19], which may modify its functional properties [36]. This points to the possibility that we may be dealing with an active redox system [37,38], with calprotectin conceivably playing a dual role during inflammation. One or the other of these roles may become the leading one, determined by environmental signals. In fact, a change of concentrations may transform reactants from pro-oxidants to anti-oxidants [37], as we observed by increasing the concentration of A9 (Figure 7d), which suggests that A9 may act as a scavenger of $\mathrm{NaOCl}$. So far, most investigations have focused on inflammatory stimulation by S100A8/A9 proteins [39]. However, recent research has indicated that oxidation of these proteins may trigger a switch, whereby they come to display anti-inflammatory functions [40]. These may be enhanced by nitrosylation [41]. Furthermore, the function of A8 and A9 might be determined also by polymerization, i.e. whether they exist as momomers, homodimers, heterodimers or tetramers [42]. Proper refolding may also be important for the protein's function. Such a mechanism could possibly explain why recombinant A8/A9 exposed to mercaptoethanol did not generate ROS. In any case this 
multitude of possible molecular forms could mean that the capacity to generate or scavenge ROS be present in only a small fraction of a heterogeneous multimeric complex.

It is true that a substantial part of our results are shown at an unphysiological $\mathrm{pH}$ and probably also hydrogen peroxide concentration. However, ours is a very artificial, simplified cell-free in vitro system, devised to explore possible oxidative and anti-oxidative phagocyte functions of calprotectin, as well as interactions with the better known ROS-generating cellular components. By varying concentrations of $\mathrm{H}^{+}$-ions, $\mathrm{H}_{2} \mathrm{O}_{2}, \mathrm{NaOCl}$, and proteins we have been able to establish procedures in which the different variables are balanced within assumedly physiological limits. Whether our findings can be validated under conditions present in intact cells or in an inflammatory, extracellular environment has to be explored in further experiments.

In the intact organism the putative interplay between MPO and calprotectin will be largely restricted to PMN, monocytes and possibly early B-lymphocytes, in which MPO gene expression has been demonstrated [43]. We suggest that on stimulation of $\mathrm{PMN}$, as an initial step, $\mathrm{O}_{2}^{-}$, generated by NADPH-oxidase, is converted to $\mathrm{H}_{2} \mathrm{O}_{2}$, which next may react with MPO. Its two reaction products, $\mathrm{H}_{2} \mathrm{O}_{2}$ and $\mathrm{HOCl}$, are membrane permeable, so they might reach cytoplasmic calprotectin. Cellular $\mathrm{H}_{2} \mathrm{O}_{2}$ may also be generated in other metabolic pathways. For instance, electrons leaking from the mitochondria [44] lead to $\mathrm{O}_{2}{ }^{-}$and $\mathrm{H}_{2} \mathrm{O}_{2}$ formation. In this way, calprotectin may become an integral part of cytoplasmic redox regulation or microbial defense mechanisms or both. Considering the very high calprotectin concentration in some cell types (PMN) and its widespread distribution, together with $\mathrm{H}_{2} \mathrm{O}_{2}$, it is hardly surprising that calprotectin has been clinically related to many disease conditionsEven in atherosclerosis [31,45].

\section{Experimental Section}

\subsection{Chemicals}

Hydrogen peroxide (30\%), 5-amino-2,3-dihydro-1,4-phtalazinedione (luminol), bis- $N$-methylacridinium nitrate (lucigenin), myeloperoxidase (MPO), phorbol 12-myristate 13-acetate (PMA), mercaptoethanol, deferoxamine mesylate, 4-hydroxybenzoic acid, sodium azide, melatonin, L-cysteine, L-histidine and human serum albumin (HSA, MW $~ 67 \mathrm{kDa}$ ) were purchased from Sigma (St. Louis, USA), and Hepes buffer from BioWhittaker (Walkersville, MD, USA). Dextran 500 (Pharmacia, Uppsala, Sweden) was dissolved in $0.9 \% \mathrm{NaCl}$ and used as a 3 or $6 \%$ solution. Sodium hypochlorite $(\mathrm{NaOCl}, 0.5 \mathrm{M}$ in $0.1 \mathrm{M} \mathrm{NaOH}$ ), purchased from $\mathrm{BDH}$ (Dorset, England), was diluted with water. Luminol and PMA were dissolved in dimethylsulphoxide (Sigma) and further diluted in water or a buffered salt solution. Phosphate-buffers of different $\mathrm{pH}$ were made by mixing appropriate portions of $0.2 \mathrm{M} \mathrm{NaH}_{2} \mathrm{PO}_{4}$ and $0.2 \mathrm{M} \mathrm{Na}_{2} \mathrm{HPO}_{4}$. Peroxidase was measured with the enhanced chemiluminescence method (ECL, Amersham Pharmacia Biotech, Oslo). Calprotectin, purified from human neutrophils [46], was generously provided by Axis-Shield (Oslo, Norway) and dialysed against Hanks' balanced salt solution (HBSS, Invitrogen, Norway) or phosphate-buffered saline before use. The two subunits (S100A8 and S100A9) preferentially combine as a heterodimer, and tend to remain associated during purification [47]. However, they may also combine as homodimers and even trimers 
or tetramers [47], so exact characterization by MW is not always possible. Cytidine deaminase (MW 52 kDa) was produced as recombinant protein [13] and dissolved in HBSS.

\subsection{Purification of recombinant S100A8 and S100A9}

Competent E. coli BL21 CodonPlus(DE3)-RIL cells were transformed with pET28-S100A8 or pET28-S100A9 [48], grown in $2 \mathrm{~L}$ of LB medium with $25 \mu \mathrm{g} / \mathrm{mL}$ kanamycin to $\mathrm{OD}_{600}$ of 1 and induced with $1 \mathrm{mM}$ isopropyl- $\beta$-D-thiogalactopyranoside (IPTG, Sigma) for $4 \mathrm{~h}$ at $30{ }^{\circ} \mathrm{C}$. Extract was prepared by sonication of the cell pellet in $40 \mathrm{mM} \mathrm{Na}_{2} \mathrm{PO}_{4}, \mathrm{pH} 8.0,300 \mathrm{mM} \mathrm{NaCl}$ (sonication buffer) and cleared with centrifugation. The cell extract was applied on a Ni-column equilibrated with sonication buffer. The column was eluted with a gradient of $50-300 \mathrm{mM}$ imidazole in sonication buffer, and purification of A8 and A9 (with and without mercaptoethanol) was monitored by protein gel electrophoresis. The $\mathrm{N}$-terminal $6 x$ His were removed by Thrombin (T-4648, Sigma) cleavage, which enhanced the CL-inducing activity of the dialysed proteins. The purified A8 migrated as a monomer of apparent molecular weight $10 \mathrm{kDa}$, while A9 migrated as a monomer and a dimer of apparent molecular weight 13 and $26 \mathrm{kDa}$ (Figure 6), respectively. Protein concentration was determined by the Bio-Rad protein assay (Bio-Rad), with BSA as a standard.

\subsection{Chemiluminescence}

A cell-free system was used as model of the respiratory burst in PMN: $\mathrm{H}_{2} \mathrm{O}_{2}+\mathrm{MPO}+$ chloride + luminol. In some experiments MPO was replaced by calprotectin. The luminol-enhanced CL was measured as relative light units in a luminometer (Luminoskan, Termo Labsystems, Helsinki, Finland), reading the samples in 96-well plates (White Cliniplate, Thermo Fisher Scientific, Vantaa-Finland). In some experiments (Figures 7, 8) we used a FLx800 luminometer (Biotek Instruments, Inc. Winooski, Vermont, USA). In relative terms the results were similar with the two luminometers, but the observed values (arbitrary light units) were quite different. Unless otherwise indicated, the recording was done at $37{ }^{\circ} \mathrm{C}$. Each well contained $25 \mu \mathrm{L} \mathrm{H} \mathrm{H}_{2} \mathrm{O}_{2}$ solution (final concentrations are indicated), 5-10 $\mu \mathrm{L}$ MPO, $50 \mu \mathrm{L}$ luminol $(0.1 \mathrm{mM}), 10-20 \mu \mathrm{L}$ test substance and buffer $(140-170 \mu \mathrm{L})$ to yield a total volume of $250 \mu \mathrm{L}$. MPO $(10-40 \mu \mathrm{g})$ was dissolved in $1 \mathrm{~mL}$ water and stored at $4{ }^{\circ} \mathrm{C}$. The activity was stable for some months, but upon further dilution it was often strongly reduced after a couple of days. The chemiluminescence was recorded (2-4 wells per group) at 1-2 minute intervals for 25-30 (or 60 minutes, Figure 3) minutes, and the integral of the response curve (AUC, area under the curve) was calculated. MPO concentration of $0.05-0.3 \mu \mathrm{g} / \mathrm{mL}$ mostly yielded AUC in the 5-30 range, but substantially increased responses were sometimes observed with modified procedures. Significant responses with MPO, calprotectin or cells were observed with 8-16 $\mu \mathrm{M} \mathrm{H}_{2} \mathrm{O}_{2}$ as stimulator. However, consistent results were best obtained at higher concentration (30-500 $\mu \mathrm{M}$ ). A control group with buffer, but without luminol and $\mathrm{H}_{2} \mathrm{O}_{2}$ was always included. Tris-buffers should be avoided because it triggers substantial CL when combined with $\mathrm{NaOCl}$. 


\subsection{Cell separation}

Human blood from healthy colleagues was collected into vacutainers containing EDTA. The granulocytes were separated as described previously [49]. Male Fisher 344 rats (Møllegaard Breeding Centre, Ejby, Denmark) were also used. They were treated in accordance with institutional and national guidelines for animal research. Rat granulocytes were prepared as follows: The rats were anaesthetized with $\mathrm{CO}_{2}$ and killed by decapitation, and the trunk blood was collected into tubes containing EDTA. One part (3-6 mL) of EDTA-blood was mixed with one part of dextran 3\% to cause aggregation and sedimentation of erythrocytes. Then $3 \mathrm{~mL}$ of Lymphoprep (Axis-Shield, Oslo, Norway) was installed underneath leucocyte-rich dextran-plasma (4-8 mL) in $15 \mathrm{~mL}$ tubes and centrifuged for $15 \mathrm{~min}$ at $600 \mathrm{~g}$ at room temperature. The bottom fraction, comprising $>95 \%$ granulocytes, was collected and washed once. The cell button was suspended in $4 \mathrm{~mL}$ lysis solution $\left(0.15 \mathrm{M} \mathrm{NH}_{4} \mathrm{Cl}, 1 \mathrm{mM} \mathrm{KHCO} 3,0.1 \mathrm{mM}\right.$ EDTA) and incubated at room temperature for 7 minutes to lyse remaining red cells. If necessary, the procedure was repeated. Rat peritoneal cells were obtained by washing the peritoneum of dead animals with $25 \mathrm{~mL}$ phosphate-buffered saline. The cells were pelleted by centrifugation and resuspended in phosphate buffer or HBSS supplied with $20 \mathrm{mM}$ Hepes buffer ( $\mathrm{pH} 7.4)$ and $5 \mathrm{mM}$ glucose.

\subsection{Statistics}

The results are given as means with their standard error (SEM). An analysis of variance (ANOVA) procedure was used to test for dose-response of cytidine deaminase and calprotectin. Student's t-test was used to assess the difference between two groups. Two-sided $\mathrm{P}$ values $<0.05$ were considered statistically significant.

\section{Conclusions}

Calprotectin (S100A8/A9), together with $\mathrm{H}_{2} \mathrm{O}_{2}$, induced luminol-dependent chemiluminescence (CL), and thus triggered formation of reactive oxygen species (ROS). Calprotectin and myeloperoxidase (MPO) might thereby collaborate on microbial killing. The CL responses elicited by calprotectin and MPO were differentially increased or decreased by varying the experimental conditions in several ways. Calprotectin $\mathrm{CL}$ was enhanced by addition of $\mathrm{NaOCl}$ to the reaction mixture. Surprisingly, however, at constant $\mathrm{NaOCl}$ concentration, this augmentation vanished when the calprotectin concentration was increased, suggesting a switch from pro-oxidant to anti-oxidant function. Possibly, calprotectin may launch an attack on microbes, but also protect our own tissues from excessive ROS exposure.

\section{Acknowledgements:}

Expression plasmids pET28-S100A8 and pET28-S100A9 were a kind gift from Philippe Tessier [48]. We also wish to thank Trine Reistad for valuable help with establishing the CL procedure. 


\section{References}

1. Hampton, M.B.; Kettle, A.J.; Winterbourn, C.C. Inside the neutrophil phagosome: Oxidants, myeloperoxidase, and bacterial killing. Blood 1998, 92, 3007-3017.

2. Kettle, A.J.; Winterbourn, C.C. Superoxide enhances hypochlorous acid production by stimulated human neutrophils. Biochim. Biophys. Acta 1990, 1052, 379-385.

3. Halliwell, B. Free radicals and oxidative damage in biology and medicine: An introduction. In Oxidative Stress in Skeletal Muscle; Reznick, Z.A.; Packer, L.; Sen, C.K.; Holloszy, J.O.; Jackson, M.J., Eds.; Birkhäuser Verlag: Basel, Switzerland, 1998; pp. 1-28.

4. Kettle, A.J.; Winterbourn, C.C. Myeloperoxidase: A key regulator of neutrophil oxidant production. Redox Rep. 1997, 3, 3-15.

5. Tobler, A.; Koeffler, H.P. Myeloperoxidase: Localization, structure, and function. In Blood Cell Biochemistry; Harris, J.R., Ed.; Plenum Press: New York, NY, USA, 1991; Vol. 3, Chapter 10, pp. 255-288.

6. Fagerhol, M.K.; Dale, I.; Andersson, T. Release and quantitation of a leukocyte derived protein (L1). Scand. J. Haematol. 1980, 24, 393-398.

7. Johne, B.; Fagerhol, M.K.; Lyberg, T.; Prydz, H.; Brandtzæg, P.; Naess-Andresen, C.F.; Dale, I. Functional and clinical aspects of the myelomonocyte protein calprotectin. J. Clin. Pathol.-Mol. Pathol. 1997, 50, 113-123.

8. Nacken, W.; Roth, J.; Sorg, C.; Kerkhoff, C. S100A9/S100A8: Myeloid representatives of the S100 protein family as prominent players in innate immunity. Microsc. Res. Tech. 2003, 60, 569-580.

9. Donato, R. S100: A multigenic family of calcium-modulated proteins of the EF-hand type with intracellular and extracellular functional roles. Int. J. Biochem. Cell Biol. 2001, 33, 637-668.

10. Corbin, B.D.; Seeley, E.H.; Raab, A.; Feldmann, J.; Miller, M.R.; Torres, V.J.; Anderson, K.L.; Dattilo, B.M.; Dunman, P.M.; Gerads, R.; Caprioli, R.M.; Nacken, W.; Chazin, W.J.; Skaar, E.P. Metal chelation and inhibition of bacterial growth in tissue abscesses. Science 2008, 319, 962-965.

11. Foell, D.; Wittkowski, H.; Vogl, T.; Roth, J. S100 proteins expressed in phagocytes: A novel group of damage-associated molecular pattern molecules. J. Leukoc. Biol. 2007, 81, 28-37.

12. Bøyum, A.; Løvhaug, D.; Seeberg, E.; Nordlie, E.M. Identification of cytidine deaminase as inhibitor of granulocyte-macrophage colony formation. Exp. Hematol. 1994, 22, 208-214.

13. Gran, C.; Bøyum, A.; Johansen, R.F.; Løvhaug, D.; Seeberg, E.C. Growth inhibition of granulocyte-macrophage colony-forming cells by human cytidine deaminase requires the catalytic function of the protein. Blood 1998, 91, 4127-4135.

14. Bøyum, A.; Rønsen, O.; Tennfjord, V.A.; Tollefsen, S.; Haugen, A.H.; Opstad, P.K.; Bahr, R. Chemiluminescence response of granulocytes from elite athletes during recovery from one or two intense bouts of exercise. Eur. J. Appl. Physiol. 2002, 88, 20-28.

15. Bøyum, A.; Tennfjord, V.A.; Gran, C.; Løvhaug, D.; Øktedalen, O.; Brandtzæg, P. Bioactive cytidine deaminase, an inhibitor of granulocyte-macrophage colony-forming cells, is massively released in fulminant meningococcal sepsis. J. Infect. Dis. 2000, 182, 1784-1787. 
16. Briheim, G.; Stendahl, O.; Dahlgren, C. Intracellular and extracellular events in luminoldependent chemi-luminescence of polymorphonuclear leukocytes. Infect. Immun. 1984, 45, 1-5.

17. Yildiz, G.; Demiryürek, A.T.; Sahin-Erdemli, I.; Kanzik, I. Comparison of antioxidant activities of aminoguanidine, methylguanidine and guanidine by luminol-enhanced chemiluminescence. $\mathrm{Br}$. J. Pharmacol. 1998, 124, 905-910.

18. Mates, J.M. Effects of antioxidant enzymes in the molecular control of reactive oxygen species toxicology. Toxicology 2000, 153, 83-104.

19. Harrison, C.A.; Raftery, M.J.; Walsh, J.; Alewood, P.; Iismaa, S.E.; Thliveris, S.; Geczy, C.L. Oxidation regulates the inflammatory properties of the murine S100 protein S100A8. J. Biol. Chem. 1999, 274, 8561-8569.

20. Test, S.T.; Weiss, S.J. Quantitative and temporal characterization of the extracellular $\mathrm{H} 2 \mathrm{O} 2$ pool generated by human neutrophils. J. Biol. Chem. 1984, 259, 399-405.

21. Valko, M.; Leibfritz, D.; Moncol, J.; Cronin, M.T.; Mazur, M.; Telser, J. Free radicals and antioxidants in normal physiological functions and human disease. Int. J. Biochem. Cell Biol. 2007, 39, 44-84.

22. Freinbichler, W.; Bianchi, L.; Colivicchi, M.A.; Ballini, C.; Tipton, K.F.; Linert, W.; Corte, L.D. The detection of hydroxyl radicals in vivo. J. Inorg. Biochem. 2008, 102, 1329-1333.

23. Ste-Marie, L.; Boismenu, D.; Vachon, L.; Montgomery, J. Evaluation of sodium 4-hydroxybenzoate as an hydroxyl radical trap using gas chromatography-mass spectrometry and high-performance liquid chromatography with electrochemical detection. Anal. Biochem. 1996, 241, 67-74.

24. Myhre, O.; Vestad, T.A.; Sagstuen, E.; Aarnes, H.; Fonnum, F. The effects of aliphatic (n-nonane), naphtenic (1,2, 4-trimethylcyclohexane), and aromatic (1,2,4-trimethylbenzene) hydrocarbons on respiratory burst in human neutrophil granulocytes. Toxicol. Appl. Pharmacol. 2000, 167, 222-230.

25. Steinbeck, M.J.; Khan, A.U.; Karnovsky, M.J. Extracellular production of singlet oxygen by stimulated macrophages quantified using 9,10-diphenylanthracene and perylene in a polystyrene film. J. Biol. Chem. 1993, 268, 15649-15654.

26. Halliwell, B.; Gutteridge, J.M. Oxygen toxicity, oxygen radicals, transition metals and disease. Biochem. J. 1984, 219, 1-14.

27. Dahlgren, C.; Briheim, G. Comparison between the luminol-dependent chemiluminescence of polymorphonuclear leukocytes and of the myeloperoxidase-hooh system - influence of $\mathrm{pH}$, cations and protein. Photochem. Photobiol. 1985, 41, 605-610.

28. Albrecht, D.; Jungi, T.W. Luminol-enhanced chemiluminescence induced in peripheral bloodderived human phagocytes: Obligatory requirement of myeloperoxidase exocytosis by monocytes. J. Leukoc. Biol. 1993, 54, 300-306.

29. Gyllenhammar, H. Effects of extracellular $\mathrm{pH}$ on neutrophil superoxide anion production, and chemiluminescence augmented with luminol, lucigenin or DMNH. J. Clin. Lab Immunol. 1989, 28, 97-102.

30. Segal, A.W.; Geisow, M.; Garcia, R.; Harper, A.; Miller, R. The respiratory burst of phagocytic cells is associated with a rise in vacuolar pH. Nature 1981, 290, 406-409. 
31. Yousefi, R.; Imani, M.; Ardestani, S.K.; Saboury, A.A.; Gheibi, N.; Ranjbar, B. Human calprotectin: Effect of calcium and zinc on its secondary and tertiary structures, and role of $\mathrm{pH}$ in its thermal stability. Acta Biochim. Biophys. Sinica 2007, 39, 795-802.

32. Trush, M. A.; Wilson, M. E.; van Dyke, K. The generation of chemiluminescence (CL) by phagocytic cells. In Methods in Enzymology; de Luca, M.A., Ed.; Academic Press, Inc.: New York, NY, USA, 1978; Vol. 57, Chapter 39, pp. 462-493.

33. Brestel, E.P. Co-oxidation of luminol by hypochlorite and hydrogen peroxide implications for neutrophil chemi-luminescence. Biochem. Biophys. Res. Commun. 1985, 126, 482-488.

34. Arnhold, J.; Mueller, S.; Arnold, K.; Grimm, E. Chemiluminescence intensities and spectra of luminol oxidation by sodium hypochlorite in the presence of hydrogen peroxide. J. Biolumin. Chemilumin. 1991, 6, 189-192.

35. Stendahl, O.; Coble, B.I.; Dahlgren, C.; Hed, J.; Molin, L. Myeloperoxidase modulates the phagocytic-activity of polymorphonuclear neutrophil leukocytes. Studies with cells from a myeloperoxidase-deficient patient. J. Clin. Invest. 1984, 73, 366-373.

36. Sroussi, H.Y.; Berline, J.; Palefsky, J.M. Oxidation of methionine 63 and 83 regulates the effect of S100A9 on the migration of neutrophils in vitro. J. Leukoc. Biol. 2007, 81, 818-824.

37. Joshi, S.; Husain, M.M.; Chandra, R.; Hasan, S.K.; Srivastava, R.C. Hydroxyl radical formation resulting from the interaction of nickel complexes of L-histidine, glutathione or L-cysteine and hydrogen peroxide. Hum. Exp. Toxicol. 2005, 24, 13-17.

38. Bonomini, F.; Tengattini, S.; Fabiano, A.; Bianchi, R.; Rezzani, R. Atherosclerosis and oxidative stress. Histol. Histopathol. 2008, 23, 381-390.

39. Ehrchen, J.M.; Sunderkotter, C.; Foell, D.; Vogl, T.; Roth, J. The endogenous Toll-like receptor 4 agonist S100A8/S100A9 (calprotectin) as innate amplifier of infection, autoimmunity, and cancer. J. Leukoc. Biol. 2009, 86, 557-566.

40. Lim, S.Y.; Raftery, M.J.; Goyette, J.; Hsu, K.; Geczy, C.L. Oxidative modifications of S100 proteins: Functional regulation by redox. J. Leukoc. Biol. 2009, 86, 577-587.

41. Lim, S.Y.; Raftery, M.; Cai, H.; Hsu, K.; Yan, W.X.; Hseih, H.L.; Watts, R.N.; Richardson, D.; Thomas, S.; Perry, M.; Geczy, C.L. S-nitrosylated S100A8: Novel anti-inflammatory properties. J. Immunol. 2008, 181, 5627-5636.

42. Korndörfer, I.P.; Brueckner, F.; Skerra, A. The crystal structure of the human (S100A8/S100A9)2 heterotetramer, calprotectin, illustrates how conformational changes of interacting alpha-helices can determine specific association of two EF-hand proteins. J. Mol. Biol. 2007, 370, 887-898.

43. Hystad, M.E.; Myklebust, J.H.; Bø, T.H.; Sivertsen, E.A.; Rian, E.; Forfang, L.; Munthe, E.; Rosenwald, A.; Chiorazzi, M.; Jonassen, I.; Staudt, L.M.; Smeland, E.B. Characterization of early stages of human B cell development by gene expression profiling. J. Immunol. 2007, 179, $3662-3671$.

44. Cadenas, E.; Davies, K.J.A. Mitochondrial free radical generation, oxidative stress, and aging. Free Rad. Biol. Med. 2000, 29, 222-230.

45. McCormick, M.M.; Rahimi, F.; Bobryshev, Y.V.; Gaus, K.; Zreiqat, H.; Cai, H.; Lord, R.S.; Geczy, C.L. S100A8 and S100A9 in human arterial wall. Implications for atherogenesis. J. Biol. Chem. 2005, 280, 41521-41529. 
46. Dale, I.; Fagerhol, M.K.; Naesgaard, I. Purification and partial characterization of a highly immunogenic human leukocyte protein, the L1-antigen. Eur. J. Biochem. 1983, 134, 1-6.

47. Teigelkamp, S.; Bhardwaj, R.S.; Roth, J.; Meinardus-Hager, G.; Karas, M.; Sorg, C. Calciumdependent complex assembly of the myeloic differentiation proteins Mrp-8 and Mrp-14. J. Biol. Chem. 1991, 266, 13462-13467.

48. Ryckman, C.; Vandal, K.; Rouleau, P.; Talbot, M.; Tessier, P.A. Proinflammatory activities of S100: Proteins S10OA8, S10OA9, and S100A8/A9 induce neutrophil chemotaxis and adhesion. J. Immunol. 2003, 170, 3233-3242.

49. Bøyum, A.; Løvhaug, D.; Tresland, L.; Nordlie, E.M. Separation of leukocytes-improved cell purity by fine adjustments of gradient medium density and osmolality. Scand. J. Immunol. 1991, $34,697-712$.

(C) 2010 by the authors; licensee Molecular Diversity Preservation International, Basel, Switzerland. This article is an open-access article distributed under the terms and conditions of the Creative Commons Attribution license (http://creativecommons.org/licenses/by/3.0/). 